\title{
Mulch and groundcover effects on soil temperature and moisture, surface reflectance, grapevine water potential, and vineyard weed management
}

\author{
Christina M Bavougian ${ }^{\text {Corresp., }}{ }^{1}$, Paul E Read ${ }^{1}$ \\ ${ }^{1}$ Department of Agronomy \& Horticulture, University of Nebraska - Lincoln, Lincoln, Nebraska, United States \\ Corresponding Author: Christina M Bavougian \\ Email address: cbavougian2@unl.edu
}

The objectives of this research were to identify alternatives to glyphosate for intra-row (under-trellis) vineyard floor management and to evaluate the potential for intra-row and inter-row (alleyway) groundcovers to reduce vegetative vigor of 'Marquette' grapevines (Vitis spp.) in a southeast Nebraska vineyard. The experiment was a randomized factorial design with 5 intra-row treatments (crushed glass mulch [CG], distillers' grain mulch [DG], creeping red fescue [CRF], non-sprayed control [NSC], and glyphosate [GLY]) and 3 interrow treatments (creeping red fescue [CRF], Kentucky bluegrass [KB], and resident vegetation [RV]). Treatments were established in 2010-2011 and measurements were conducted during 2012 and 2013 on 5- and 6-year-old vines. Soil temperatures were mostly higher under mulches and lower under intra-row groundcovers, compared to GLY. Weed cover in CG, DG, and CRF treatments was the same or less than GLY. At most sampling dates, inter-row soil moisture was lowest under KB. Intra-row soil moisture was highest under DG mulch and lowest under CRF and NSC; CG had the same or lower soil moisture than GLY. Surprisingly, we did not detect differences in mid-day photosynthetically active radiation (PAR) reflectance, despite visual differences among the intra-row treatments. Mid-day vine water potential did not differ among treatments. We concluded it is not necessary to maintain a bare soil strip under established vines in this region, where soil fertility and moisture are non-limiting. 
1 Mulch and groundcover effects on soil temperature and moisture, surface reflectance,

2 grapevine water potential, and vineyard weed management

3 Christina M. Bavougian ${ }^{1 *}$ and Paul E. Read ${ }^{2}$

$4 \quad{ }^{1}$ Department of Agronomy \& Horticulture, University of Nebraska-Lincoln. 279 Plant Science

5 Hall, Lincoln, NE 68583, USA

$6 \quad{ }^{2}$ Department of Agronomy \& Horticulture, University of Nebraska-Lincoln. 377 Plant Science

7 Hall, Lincoln, NE 68583, USA

8

9 Corresponding author:

10 Christina Bavougian

11

12 Email address: cbavougian2@unl.edu

13

14

15

16

17

18

19

20

21

22

23 


\section{Abstract}

25
The objectives of this research were to identify alternatives to glyphosate for intra-row (under-trellis) vineyard floor management and to evaluate the potential for intra-row and inter-row (alleyway) groundcovers to reduce vegetative vigor of 'Marquette' grapevines (Vitis spp.) in a southeast Nebraska vineyard. The experiment was a randomized factorial design with 5 intra-row treatments (crushed glass mulch [CG], distillers' grain mulch [DG], creeping red fescue [CRF], non-sprayed control [NSC], and glyphosate [GLY]) and 3 inter-row treatments (creeping red fescue [CRF], Kentucky bluegrass [KB], and resident vegetation [RV]). Treatments were established in 2010-2011 and measurements were conducted during 2012 and 2013 on 5- and 6-year-old vines. Soil temperatures were mostly higher under mulches and lower under intra-row groundcovers, compared to GLY. Weed cover in CG, DG, and CRF treatments was the same or less than GLY. At most sampling dates, inter-row soil moisture was lowest under KB. Intra-row soil moisture was highest under DG mulch and lowest under CRF and NSC; CG had the same or lower soil moisture than GLY. Surprisingly, we did not detect differences in mid-day photosynthetically active radiation (PAR) reflectance, despite visual differences among the intra-row treatments. Mid-day vine water potential did not differ among treatments. We concluded it is not necessary to maintain a bare soil strip under established vines in this region, where soil fertility and moisture are non-limiting. 


\section{Introduction}

47 Midwestern vineyards are often situated on land that has been converted from row-crop agriculture. Due to grapevines' (Vitis spp.) perennial nature, vineyards require much less soil disturbance through cultivation than conventionally grown corn (Zea mays L.), soybean [Glycine $\max ($ L.) Merr.] and wheat (Triticum aestivum L.). The soil-conserving practice of maintaining permanent sod cover between vineyard rows is popular with grape growers in the upper Midwest and contributes to the sustainability of vineyard agroecosystems. However, the "grower standard" of spraying glyphosate or other herbicides under the vine rows to keep a weed-free bare strip under the trellis is problematic.

Overuse of glyphosate in agriculture contributes to environmental problems such as evolution of resistant weed populations and economic problems including vine die-back due to trunk damage from overspray. Glyphosate treatments decreased cold hardiness and increased winter trunk cracking in several woody species (Daniel et al., 2009; Rosenberger et al., 2010); we propose that trunk splitting and vine dieback in vineyards previously assumed to be frost/freeze damage could be caused by glyphosate overspray. Mulches and groundcovers have been identified as potential alternatives to herbicides in vineyards. Their benefits include improved soil structure, reduced soil erosion and increased water infiltration \{DeVetter, 2015 $63 \# 340\}$.

In areas with ample rainfall, soils high in fertility and organic matter may produce an overabundance of grapevine vegetative growth. High vigor, or capacity for growth, is demonstrated in vines whose large, dense canopies result in low light penetration (Byrne \& Howell, 1978). The condition of excessive vigor causes many problems. Self-shading is the most

68 dire consequence; overly vigorous vines may lead to reductions in fruit yield and quality (Shaulis 
69 et al., 1966), cold tolerance (Byrne \& Howell, 1978), and the next growing season's fruitfulness

70 (Shaulis et al., 1966). Decreased fruitfulness causes subsequent yield reduction, which increases

71 vegetative vigor - contributing to the cyclic nature of this problem (Byrne \& Howell, 1978). The

72 canopy density of high vigor vines creates unfavorable canopy microclimate conditions; reduced

73 air movement and high humidity favor disease incidence (Smart \& Robinson, 1991). Hedging,

74 summer pruning, and leaf removal become necessary under conditions of excessive vine vigor,

75 while normal activities such as dormant pruning and shoot positioning take much longer on

76 overly vigorous vines \{Smart, $1991 \# 148\}$. Many reports show the potential for groundcovers to

77 reduce excessive vine vigor (Giese et al., 2014; Giese et al., 2015; Hatch et al., 2011; Tesic et al.,

78 2007) which can reduce labor requirements and improve fruit yield and quality. Some mulches

79 increase the amount of solar radiation that is reflected, which may improve the light environment

80 within the canopy (Smart et al., 1988).

81 This project compared five intra-row (under-trellis) management strategies: crushed glass

82 mulch, dried distillers' grain mulch, creeping red fescue (Festuca rubra L.) groundcover,

83 glyphosate (bare soil) and non-sprayed control. Due to prohibitively high transportation costs

84 associated with shipping glass to recycling facilities, most municipal waste glass is sent to local

85 landfills instead $\{$ Niesse, $2015 \# 341\}\{$ Hill, $2016 \# 342\}$. Horticultural applications such as

86 vineyard mulch can remove glass from the waste stream. Dried distillers' grains, a co-product of

87 the ethanol production process, is often utilized in conventional livestock feed programs. A

88 surplus of distillers' grains may become available as a result of projected increases in ethanol

89 production. Researchers have recently discovered this material's potential to reduce weed

90 germination and emergence (similar to pre-emergence herbicides) when applied to the soil

91 surface (Boydston et al., 2008). Our research evaluated the previously-mentioned intra-row 
92 groundcovers, as well as inter-row groundcover treatments: creeping red fescue, Kentucky

93 bluegrass (Poa pratensis L.) and resident vegetation which was dominated by orchard grass

94 (Dactylis glomerata L.). Grass species differ in root structure and water use efficiency \{Fransen,

$951998 \# 343\}$; therefore, they could affect grapevine growth and water status differently.

96 The objectives of this research were to identify alternatives to synthetic chemicals used in

97 vineyard floor management, and to reduce grapevine vegetative vigor using intra-row

98 groundcovers and different inter-row groundcover species. In this paper, we compare the inter-

99 row and intra-row vineyard floor management treatment effects on soil temperature, surface

100 reflectance, soil moisture, vine water potential and weed control. Grower recommendations and

101 practical interpretation of the data are included.

102

\section{Materials \& Methods}

104 Site description

105 Research for this study was conducted at Fox Run Farms, a diversified family farm in Brainard,

106 NE (latitude $41.18 \mathrm{~N}$; longitude -97.00 W) from August 2010 to November 2013. The soil is a

107 Hastings silty clay loam with $4 \%$ organic matter. The two-acre vineyard was planted in spring

1082007 with own-rooted 'Marquette' vines, a cold-hardy and disease-resistant red wine grape

109 hybrid from the University of Minnesota's breeding program released in 2006 (Minnesota,

110 2017). Rows were oriented north-south with vines $2.4 \mathrm{~m}$ apart in rows $3 \mathrm{~m}$ apart. The vineyard

111 was situated on a south-facing slope of approximately 3 percent. Vines were trained to cordons

$1120.9 \mathrm{~m}$ high with vertical shoot positioning.

\section{Treatments and experimental design}

114 The experimental layout was a completely randomized factorial design with four replications. 
115 Five intra-row treatments [recycled crushed glass mulch (CG), dried distillers' grain mulch

116 (DG), 'Boreal' creeping red fescue (CRF), non-sprayed control (NSC) and glyphosate (GLY)]

117 and three inter-row (alleyway) treatments ['Boreal' creeping red fescue (CRF), 'Park' Kentucky

118 bluegrass (KB), and resident vegetation (RV) which was dominated by orchard grass] were

119 established in the research plots. The NSC plots were initially seeded with 'Dalkeith'

120 subterranean clover, which did not survive well over winter and were thereafter maintained as

121 non-sprayed control.

122 The treatment combinations were applied to three-vine plots, which included the intra-row

123 strip and inter-rows on both sides of the vines, with a buffer row between adjacent plots. Intra-

124 row treatments were applied to a 0.9-m-wide area under the vines, while 2.1-m-wide strips of

$125 \mathrm{CRF}, \mathrm{KB}$, and RV were maintained in the inter-rows. Measurements were taken on and around

126 the middle vine in each plot, to eliminate edge effects. Inter-row groundcover plots were

127 prepared by treating the resident groundcover with GLY, and then seeded in September 2010

128 with a 56-cm over-seeder (Bluebird International, Charlotte, NC). KB was seeded at a rate of 15

$129 \mathrm{~g} \mathrm{~m}^{2}$; CRF seeding rate was $34 \mathrm{~g} \mathrm{~m}^{2}$. Intra-row groundcovers were hand broadcast and raked in.

130 All groundcover plots were watered three times per week for six weeks. Inter-rows were

131 periodically mown by the grower; intra-row groundcovers (CRF and NSC) were mown once

132 during each growing season using a push mower or string trimmer. GLY was applied 2-3 times

133 each season using a backpack sprayer at $1.12 \mathrm{~kg} \mathrm{ha}^{-1}$ acid equivalent, per grower standard

134 practice. CG was initially applied at a depth of $7 \mathrm{~cm}$ in June 2011 . The material was obtained

135 from MileStone Local Surfaces in Lincoln, NE and consisted of municipal waste glass which

136 was mostly clear. The crushed glass shifted and settled more than expected, so the plots were

137 renovated in March 2013. Clear glass was no longer available locally, and a replacement of 
138 mostly brown crushed glass was used. DG was applied at a rate of $1.6 \mathrm{~kg} \mathrm{~m}^{2}$ in June 2011,

139 reapplied in September 2011, and twice during each growing season in 2012 and 2013. This

140 material was obtained from the University of Nebraska Department of Animal Science feed mill

141 near Mead, Nebraska; typical chemical analysis of DG is $4.5 \%$ nitrogen, $1.1 \%$ phosphorus, and

142 1.3\% potassium (Blume, 2007). Most data were collected in 2012 and 2013. Grapevine

143 phenological stages were recorded using the Eichhorn-Lorenz scale, as described by Coombe 144 (1995).

\section{Soil temperature and chemical composition}

146 Intra-row soil temperatures were measured using a digital thermometer with a $25.4 \mathrm{~cm}$

147 thermocouple probe (model HH508, Omega, Stamford, CT). On each sampling date, the probe

148 was inserted to its full depth twice for each plot (in the center of the vine row approximately 30

$149 \mathrm{~cm}$ to the north and south of the center vine). Measurements were made between 1100 and 1300

150 CDT on May 28, 2012, April 5, 2013, and May 24, 2013. Soil sampling was conducted in

151 NovemPber 2013. Two samples were collected from each intra-row and inter-row treatment,

152 ignoring possible interactions between treatments. Each sample consisted of 3 soil cores to 20

$153 \mathrm{~cm}$ depth, composited and submitted to Midwest Laboratories (Omaha, NE) for analysis. Mean

$154 \mathrm{pH}$ was 6.8 and organic matter (loss on ignition) was 3.9\% (Supplemental data file). DG

155 appeared to dramatically increase nitrate, phosphorus, and potassium in the top $20 \mathrm{~cm}$ of soil,

156 though statistical analysis was not conducted.

\section{Surface reflectance and canopy transmittance}

158 Photosynthetically active radiation (PAR; 400-700 nm) was measured using a line quantum

159 sensor (model LI-191SA, LI-COR Biosciences, Lincoln, NE), and recorded by a data logger

160 (model CR 23X, Campbell, Logan, UT) between 1200 and 1400 CDT on July 25, 2012. This 
161 was a sunny day between veraison and harvest. Surface reflectance (reflected PAR) was

162 measured with the quantum sensor inverted below the cordon. Transmitted PAR was measured

163 with the quantum sensor face up, just below the cordon. Percent transmittances were calculated

164 by dividing the transmitted PAR by the ambient PAR (measured above the canopy).

\section{Soil water content}

166 Soil volumetric water content (VWC) was measured in the field, using a soil moisture meter

167 (FieldScout TDR 300, Spectrum Technologies, Inc., Aurora, IL) which utilizes time domain

168 reflectometry. Measurements were taken using the standard soil setting; the instrument did not

169 allow site-specific calibration. Readings of the average VWC in the top $0.2 \mathrm{~m}$ of soil, in both

170 inter-rows and intra-rows of each plot, were repeated approximately every two weeks from

171 bloom until veraison in 2012 and 2013. Each data point is an average of three measurements.

172 Mulches were pushed aside before inserting the instrument, and replaced afterward.

\section{Stem water potential}

174 Mid-day stem water potentials $(\Psi)$ were measured using a pressure chamber (model 2005HGPL,

175 Soil Moisture Equipment Corp., Santa Barbara, CA), according to the method described by

176 Williams (2001). Measurements were repeated approximately every two weeks from bloom until

177 veraison in 2012 and 2013 between 1200 and 1300 CDT. At each sampling date, one

178 undamaged, fully expanded leaf on the center vine in each plot was wrapped in aluminum foil

179 and sealed in a plastic zip-top sandwich bag to stop evapotranspiration for at least 60 minutes

180 before sampling. Scissors were used to make a clean petiole cut, and $\Psi$ measurements were taken 181 within 60 seconds of removing leaves from the vines.

\section{Weed cover}


183 Intra-row percent weed cover was estimated using the Braun-Blanquet method to quantify visual

184 observations of weed coverage (Andújar et al., 2010; Wikum \& Shanholtzer, 1978). On three

185 dates (September 7, 2011, June 25, 2012, and May 24, 2013), visual weed ratings for each plot

186 were recorded by two observers for two randomly-placed $0.9 \mathrm{~m}^{2}$ quadrats. The weed species

187 most frequently observed were dandelion (Taraxacum officinale agg.), common lambsquarters

188 (Chenopodium album L.), redroot pigweed (Amaranthus retroflexus L.), shepherd's purse

189 (Capsella bursa-pastoris L.), goose grass (Eleusine indica [L.] Gaertn), and prostrate knotweed

190 (Polygonum aviculare L.).

\section{Statistical analysis}

192 Data were analyzed using SAS/STAT® Version 9.2 (SAS Institute, Cary, NC). For each data set,

193 a repeated measures analysis of variance (ANOVA) was implemented using the GLIMMIX

194 procedure. Appropriate covariance structures were determined by fit statistics (smallest AICC).

195 All two-way and three-way interactions were tested for significance in each ANOVA; significant

196 main effects and interactions are reported in the results. All significance tests used $p<0.05$.

\section{Results \& discussion}

199 Weather conditions during 2012 and 2013 growing seasons

200 Climate data were recorded at a High Plains Regional Climate Center weather station in David

201 City, NE (13 km from the research site). Average daily minimum and maximum temperatures

202 and total monthly precipitation for 2012 and 2013 growing seasons are presented in Table 1 . In

2032012 the spring and early summer were considerably warmer than in 2013, with total heat

204 accumulation of 2101 and 1776 GDD (base $10^{\circ} \mathrm{C}$; average daily temperature method) during the

205 growing seasons of 2012 and 2013, respectively. 2012 was also a drier growing season with 
marked differences in precipitation between March, May, July, and September of the two years.

\section{Soil temperature}

208 Analysis of variance showed a significant interaction of treatment by date for intra-row soil

209 temperatures (Table 2). In May of each year, the groundcover treatments lowered soil

210 temperature in the top $25.4 \mathrm{~cm}$, while mulch treatments raised soil temperature, relative to bare

211 soil (GLY). On April 5, 2013, CG had higher soil temperatures and CRF had lower soil

212 temperatures than DG, NSC, and GLY plots, which did not differ.

213 In May of 2012 and 2013, CRF and NSC intra-row plots had lower soil temperatures than

214 GLY plots. In April 2013, only CRF had lower soil temperature than GLY. The groundcover

215 treatments may have reduced soil temperatures because of the evaporative demand of the

216 vegetation. These data support previous research reporting lower soil temperature in groundcover

217 plots than in bare soil (van Huyssteen et al., 1984), although not all results have been consistent.

218 In a California study, neither triticale nor rye groundcovers influenced soil temperature

219 compared to tilled bare soil (Steenwerth \& Belina, 2008).

In May 2012, CG and DG treatments had higher soil temperatures than GLY. In April

221 2013, only CG plots were warmer than GLY plots, while in May 2013, DG plots had higher soil

222 temperature than GLY and CG soils were significantly warmer than those with DG. Mulches can

223 have cooling or warming effects on the soil depending on the type of material used, because they

224 change the radiation and energy balances at the soil surface. Mulches that reduce evaporation

225 and shade the soil surface from incoming solar radiation generally have a cooling effect on soils

226 (Ham et al., 1993). White woven reflective material (Sandler et al., 2009) and crushed mussel

227 shell mulch (Creasy et al., 2007; Leal, 2007) decreased soil temperatures relative to herbicide

228 control, while mulching with gravel (Nachtergaele et al., 1998) and silver reflective mulch 
229 (Hutton \& Handley, 2007) increased soil temperatures. Researchers in Kansas concluded that

230 mid-day soil temperatures were highest under mulches that efficiently transmit shortwave

231 radiation while preventing the escape of longwave radiation (Ham et al., 1993). This could

232 explain the soil heating effect of the $\mathrm{CG}$ in this research. DG plots had higher soil temperatures

233 in May of 2012 and 2013, converse to previous research which reported a buffering effect of

234 organic mulches on soil temperature (Mundy \& Agnew, 2002). It has been suggested that heat

235 conduction between mulch and soil surface affects the ability of the mulch to moderate soil

236 temperature (Ham et al., 1993), which may be one reason why straw mulch had such a cooling

237 effect (Fourie \& Freitag, 2010) while DG increased soil temperatures in this study. A likelier

238 explanation is that soil heating resulted from increased microbial activity under the DG mulch, as

239 documented by Boydston et al. (2008).

240 Soil temperature can influence many aspects of vine growth and soil processes such as

241 microbial respiration, organic matter decomposition rates and nutrient availability. Soil

242 temperatures have been shown to affect cytokinin content in grapevine roots, percentage of buds

243 that break, shoot length and dry weight, and yield (Kliewer, 1975). The percentage of buds that

244 broke per vine increased with soil temperature, while leaf area, fruit set and cluster weights were

245 highest at lower soil temperatures (Kliewer, 1975). Soil temperature may also affect bud-break

246 timing, which could be important in cool climates where early-budding grape cultivars risk frost

247 damage in spring (Kliewer, 1975; Sandler et al., 2009). However, the magnitude of differences in

248 this research (approximately $2{ }^{\circ} \mathrm{C}$ difference between coolest and warmest treatments) probably

249 was not sufficient to affect vine growth and no differences in bud-break or growth stage were

250 observed between the treatments.

251 Surface (vineyard floor) reflectance and canopy transmittance 
252 The amount and type of reflected radiation depends on the properties of the soil surface,

253 vegetation or mulch beneath vines (Meinhold et al., 2010). None of the treatments in this

254 research affected the intra-row surface PAR reflectance on July 25, 2012 (Supplemental data file;

255 average reflectance over all treatments was $4.5 \%$ of incoming PAR). This result was unexpected

256 because there were obvious visual differences among the treatments. Many types of mulch have

257 been found to increase PAR reflectance compared to bare soil, including crushed glass (Mejias-

258 Barrera, 2012; Ross, 2010), and gravel (Nachtergaele et al., 1998). Reflected radiation from the

259 vineyard floor can be an important component of vines' total photosynthetically active radiation

260 (PAR) interception, which can affect fruit composition (Smart et al., 1988). Canopy density also

261 influences vineyard floor surface reflectance, because a portion of the reflected light was

262 originally transmitted through the canopy and thus alters the spectral quality of the incident light

263 on the underlying surface. This is particularly applicable where vines are trained to a north-south

264 trellis, since vines shade the intra-row area at mid-day (Mejias-Barrera, 2012). Because the

265 vines' canopies were at full cover when PAR transmittance was measured (near veraison),

266 transmitted light could have been saturated, obscuring possible differences due to canopy density

267 and limiting the amount of light available to reflect. It is also possible that there could have been

268 differences between the treatments which would have appeared if transmittance had been

269 measured earlier in the season before canopy closure. A challenging aspect of reflective mulches

270 is that they must remain clean and free of debris in order to function as intended (Coventry et al.,

271 2005; Sandler et al., 2009). In this study, grass clippings blew onto the intra-row treatments

272 following mowing of inter-rows, which could have masked differences in the surface reflectance.

273 It is also possible that the quality of light, specifically the ratio of red to far-red radiation (which

274 we did not measure), was altered by the reflective mulches; this ratio is involved in the 
275 regulation of phytochrome, which is important to many facets of grapevine growth and 276 development (Smart et al., 1988).

Soil water content. The volumetric soil water content values measured in this study were

278

279

280

281

282

283

284

285

286

287

288

289

290

291

292

293

294

295

296

297

unrealistically high due to calibration error; however, there were consistent treatment

differences. We determined that investigation of relative differences would be appropriate. For each sampling date, the data were converted to ratios comparing each treatment mean to the grower standard treatment mean (RV for inter-rows and GLY for intra-rows) to describe the relationships between treatments.

In 2012, soil $\mathrm{VWC}_{\text {ratio }}(0.2 \mathrm{~m}$ depth $)$ in the inter-rows was affected by groundcover treatments on May $11(\mathrm{~KB}<\mathrm{CRF}<\mathrm{RV})$, June $12(\mathrm{~KB}<\mathrm{RV})$ and July $10[\mathrm{~KB}<(\mathrm{CRF}=\mathrm{RV})]$; on the other sampling dates, there were no differences in inter-row $\mathrm{VWC}_{\text {ratio }}$ (Table 3). In 2013, KB had lower $\mathrm{VWC}_{\text {ratio }}$ than $\mathrm{RV}$ on June $10 ; \mathrm{KB}$ and $\mathrm{CRF}$ had lower $\mathrm{VWC}_{\text {ratio }}$ than $\mathrm{RV}$ on July 3; $\mathrm{KB}$ had lower $\mathrm{VWC}_{\text {ratio }}$ than both CRF and RV on July 12 and July 26; on June 28, the treatments did not differ. Plant species vary greatly in their evapotranspiration rates, and therefore their effects on soil moisture (Lopes et al., 2004). Differences in soil water content between the inter-row plots could have been influenced by stand density, rooting depth and water use of the groundcover species.

Intra-row soil moisture was highest for DG on each sampling date in 2013 and most dates in 2012 (Table 4). Surface-applied DG mulch absorbs water and reduces evaporation from the soil (Blume, 2007). A German study reported increased soil water content in vineyard plots mulched with sawdust (Huber et al., 2003) which has a similar texture and particle size to the DG. Mundy \& Agnew (2002) measured higher water content in vineyard soils under a variety of organic mulch treatments. Intra-row VWC was similar for CG and GLY on most dates in 2012, 
298 while in 2013 GLY had higher VWC than CG on all dates except June 10. Gravel mulch has

299 been reported to increase evaporation from soil (Nachtergaele et al., 1998). Conversely, research

300 in New Zealand has found greater soil water content under CG compared to bare soil (Ross,

301 2010). On many dates in 2012 and 2013, CRF had the lowest VWC of all intra-row treatments.

302 Although NSC generally had only slightly greater soil water content than CRF, NSC had higher

303 VWC than CG on August 8 of 2013 (Table 4). Other studies have found lower soil water content

304 under intra-row groundcover treatments, compared to herbicide controls (Giese et al., 2015;

305 Olmstead, 2006), although in Iowa, intra-row CRF plots had higher VWC than herbicide plots

306 (Wasko, 2010). Soil moisture is also important in the functioning of biological processes.

307 Increased soil microbial activity was measured under 'Chardonnay' vines following application

308 of mulched inter-row groundcover residue, which was attributed to higher soil water content in

309 the mulched plots (Jacometti et al., 2007).

310 Soil water content is an important variable affecting vine phenology and fruit yield and

311 quality. Soil water availability affects rooting patterns and density of grapevines. Increasing soil

312 water content encourages root growth; root systems explored a much greater area in overhead

313 sprinkler-irrigated vineyards than in drip-irrigated vineyards because there was a greater volume

314 of moistened soil under sprinkler irrigation (Soar \& Loveys, 2007). Vines grown under

315 groundcover often have deeper roots because of reduced soil water content near the surface,

316 where groundcover roots are more competitive (Smart et al., 2006). Too much moisture can

317 contribute to excess vine vigor, while too little may restrict growth and yield (Smart, 1985).

318 Excess vigor generates self-shading and a lack of vine balance (Wheeler et al., 2008). In regions

319 where grapevines tend to produce overly vigorous vegetative growth, manipulation of soil water

320 content may provide a useful method to correct the problem. Shoot growth, pruning weight and 
321 berry weight were increased by irrigation (Hamman \& Dami, 2000). However, "excessive soil

322 moisture" was observed under straw mulch in Iowa, which reduced berry size and likely delayed

323 fruit ripening because of unlimited uptake of water after veraison (Wasko, 2010). Waterlogging

324 can also restrict oxygen availability to roots, thereby reducing vine growth. Soil water status can

325 affect fruit and wine quality parameters such as berry size, color and anthocyanins (Williams \&

326 Matthews, 1990). Mowing may be used to temporarily reduce groundcover water use, thereby

327 making moisture more available to vines during key growth periods such as bloom and berry set

328 (Centinari et al., 2013).

329 Vine water potential

330 Mid-day stem water potentials $(\Psi)$ were not affected by inter-row or intra-row treatments in

331 either year of this study; overall means for each sampling date ranged from -0.9 to $-0.4 \mathrm{MPa}$.

332 These results support previous findings that intra-row groundcovers reduced soil moisture but

333 did not significantly change predawn leaf $\Psi$, mid-day leaf $\Psi$ or xylem $\Psi$ (Giese et al., 2015).

334 Olmstead and colleagues found reduced (more negative) vine water potential in some

335 groundcover treatments, although the values were not indicative of water stress (Olmstead et al.,

336 2001) which has commonly been defined as mid-day stem $\Psi$ values below -1.3 to $-1.6 \mathrm{MPa}$

337 (Lovisolo et al., 2010). Researchers in Oregon and California have reported little effect of inter-

338 row groundcovers on leaf water potential (Ingels et al., 2005; Schreiner \& Sweet, 2005; Sweet \&

339 Schreiner, 2010). In Virginia, intra-row creeping red fescue reduced stem $\Psi$ relative to herbicide

340 strip, but vines in the groundcover plots did not show symptoms of water stress (Hatch et al.,

341 2011). In our study VWC was measured only in the top $0.2 \mathrm{~m}$ of soil, while the roots of the

342 grapevines likely penetrate much deeper $\{$ Smart, $2006 \# 184\}$. This is probably the main reason

343 why the intra-row and inter-row treatments affected soil moisture but not stem $\Psi$. 
In some cases, low (more negative) vine water potential has been associated with a

345 reduction in vegetative vigor which is desirable in areas with abundant rainfall and soil fertility.

346 Hatch et al. found intra-row creeping red fescue decreased leaf layer number by $21 \%$ and

347 pruning weight by $47 \%$, in addition to reducing stem $\Psi$ in a Virginia 'Cabernet Sauvignon'

348 vineyard (2011). A study in North Carolina reported slower shoot growth and reduced pruning

349 weights as a result of intra-row groundcover although water potential differences were not

350 significant (Giese et al., 2014), which indicates vineyard floor vegetation affected grapevines in

351 ways other than competition for water.

\section{Weed cover}

353 Analysis of variance identified a significant interaction between intra-row treatment and date

354 regarding weed cover. CG and DG provided complete weed control ( $0 \%$ weed cover) in

355 September 2011 but did not control weeds as well in June 2012 or May 2013 (Table 5). This was

356 likely a result of the time of year, as well as length of time since the treatments had been

357 established. GLY weed control was progressively worse on each of the three dates, which was

358 probably because of seasonal differences in weed seed germination and timing of herbicide

359 application. The weeds in GLY plots were new seedlings that had germinated, rather than

360 perennial weeds that were not controlled by the treatment.

361 Collectively, our results suggest that it is not advantageous to maintain a weed-free strip

362 under the vine row in established vineyards where resources are not limiting. Other researchers

363 have also determined that eliminating intra-row vegetation did not benefit established vineyards

364 on deep, fertile soils (Nonnecke et al., 2011; Wasko, 2010) and that intra-row living mulches or

365 groundcovers can reduce excessive vegetative vigor (Giese et al., 2014; Giese et al., 2015; Hatch

366 et al., 2011). By establishing a continuous vineyard floor groundcover or allowing resident 
367 vegetation to grow, growers can reduce their use of synthetic chemicals and provide habitat for

368 arthropods and other wildlife.

369

370 Conclusions

371 This study supports a growing body of evidence that maintenance of a weed-free strip under

372 mature vines is unnecessary in vineyards situated on deep, fertile soils. Intra-row groundcovers

373 can reduce growers' reliance on synthetic chemicals and reduce excess vegetative vigor.

374 Mulches evaluated in this research successfully controlled weeds, but elimination of competition

375 from weeds may not be desirable in fertile, vigorous vineyards.

376 For a potential vineyard site, if resident vegetation is appropriate (i.e., dominated by cool-

377 season grasses) then it can be left in place as an inter-row groundcover. The vine rows can be

378 disked or sprayed with herbicide in preparation for setting out new rooted cuttings. Even in areas

379 where vigor reduction is desired for older vines, new plantings should be maintained with a

380 weed-free strip or area around each vine in order to assist with establishment (Bordelon \&

381 Weller, 1997). Mulches present a sustainable alternative to GLY and other herbicides for this

382 purpose. DG may be useful for first-year vineyards because it increases soil moisture retention

383 and would only need to be applied one to two times to control weeds for the first season;

384 thereafter, RV could be allowed to colonize the vine row, or an intra-row groundcover could be

385 seeded. CG gave excellent weed control the first season, but because of transportation costs,

386 labor, and logistics of application, it would only be practical if there is a local inexpensive

387 source.

388

389 Acknowledgements 
390 The authors wish to acknowledge the technical assistance of Stephen Gamet, Charles Francis,

391 Timothy Arkebauer, Elizabeth Walter-Shea, Benjamin Loseke, Vivian Shi, David Scoby, Mark

392 Mesarch, and Erin Blankenship. We also thank the Bailey family at Fox Run Farms in Brainard,

393 NE for hosting this research.

394

395

396

397

398

399

400

401

402

403

404

405

406

407

408

409

410

411

412

413

414

415

416

417

418

419

420

421

422

423

424

425

426

427

428

429

References

Andújar D, Ribeiro A, Carmona R, Fernández-Quintanilla C, and Dorado J. 2010. An assessment of the accuracy and consistency of human perception of weed cover. Weed Research 50:638-647. 10.1111/j.1365-3180.2010.00809.x

Blume D. 2007. Method for the use of distiller's grain as herbicide and fertilizer. Patent \#US7183237 B2. United States: D Blume.

Bordelon BP, and Weller SC. 1997. Preplant cover crops affect weed and vine growth in firstyear vineyards. HortScience 32:1040-1043.

Boydston RA, Collins HP, and Vaughn SF. 2008. Response of weeds and ornamental plants to potting soil amended with dried distillers grains. HortScience 43:191-195.

Byrne ME, and Howell GS. 1978. Initial response of Baco noir grapevines to pruning severity, sucker removal, and weed control. American Journal of Enology and Viticulture 29:192198.

Centinari M, Filippetti I, Bauerle T, Allegro G, Valentini G, and Poni S. 2013. Cover crop water use in relation to vineyard floor management practices. American Journal of Enology and Viticulture 64:522-526. 10.5344/ajev.2013.13025

Coombe BG. 1995. Adoption of a system for identifying grapevine growth stages. Australian Journal of Grape and Wine Research 1:104-110.

Coventry JM, Fisher KH, Strommer JN, and Reynolds AG. 2005. Reflective mulch to enhance berry quality in Ontario wine grapes. Acta Horticulturae 689:95-102.

Creasy GL, Perez GL, Crawford M, Ibbotson L, Tompkins J, Creasy K, Wells G, Nicol I, Harrison R, and Sherlock RR. 2007. Influence of natural reflective mulch on Pinot noir grape and wine quality. New Zealand: Centre for Viticulture and Oenology. p 1-59.

Daniel K, Mathers HM, and Case LT. 2009. Effect of postemergent herbicide on sucker removal/injury of field tree liners [Abstract]. HortScience 44:1038.

Fourie JC, and Freitag K. 2010. Soil management in the Breede River Valley wine grape region, South Africa. 2. Soil temperature. South African Journal of Enology and Viticulture 31:165-168.

Giese G, Velasco-Cruz C, Roberts L, Heitman J, and Wolf TK. 2014. Complete vineyard floor cover crops favorably limit grapevine vegetative growth. Scientia Horticulturae 170:256266. http://dx.doi.org/10.1016/j.scienta.2014.03.011

Giese G, Wolf TK, Velasco-Cruz C, Roberts L, and Heitman J. 2015. Cover crop and root pruning impacts on vegetative growth, crop yield components, and grape composition of Cabernet Sauvignon. American Journal of Enology and Viticulture 66:212-226. 10.5344/ajev.2014.14100

PeerJ reviewing PDF | (2017:12:22845:1:1:NEW 8 May 2018) 
430

431

432

433

434

435

436

437

438

439

440

441

442

443

444

445

446

447

448

449

450

451

452

453

454

455

456

457

458

459

460

461

462

463

464

465

466

467

468

469

470

471

472

473
Ham JM, Kluitenberg GJ, and Lamont WJ. 1993. Optical properties of plastic mulches affect the field temperature regime. Journal of the American Society for Horticultural Science 118:188-193.

Hamman RA, and Dami IE. 2000. Effects of irrigation on wine grape growth and fruit quality. HortTechnology 10:162-168.

Hatch TA, Hickey CC, and Wolf TK. 2011. Cover crop, rootstock, and root restriction regulate vegetative growth of Cabernet Sauvignon in a humid environment. American Journal of Enology and Viticulture 62:298-311. 10.5344/ajev.2011.11001

Huber L, Porten M, Eisenbeis G, and Rühl E. 2003. The influence of organically managed vineyard-soils on the phylloxera-populations and the vigour of grapevines. Acta Horticulturae 617:55-59.

Hutton MG, and Handley DT. 2007. Effects of silver reflective mulch, white inter-row mulch, and plant density on yields of pepper in Maine. HortTechnology 17:214-219.

Ingels CA, Scow KM, Whisson DA, and Drenovsky RE. 2005. Effects of cover crops on grapevines, yield, juice composition, soil microbial ecology, and gopher activity. American Journal of Enology and Viticulture 56:19-29.

Jacometti MA, Wratten SD, and Walter M. 2007. Enhancing ecosystem services in vineyards: using cover crops to decrease botrytis bunch rot severity. International Journal of Agricultural Sustainability 5:305-314. 10.1080/14735903.2007.9684830

Kliewer WM. 1975. Effect of root temperature on budbreak, shoot growth, and fruit-set of 'Cabernet Sauvignon' grapevines. American Journal of Enology and Viticulture 26:82-89.

Leal GR. 2007. Influence of reflective mulch on Pinot noir grape and wine quality M.S. Lincoln University.

Lopes C, Monteiro A, Ruckert FE, Gruber B, Steinberg B, and Schultz HR. 2004. Transpiration of grapevines and co-habitating cover crop and weed species in a vineyard. A "snapshot" at diurnal trends. Vitis 43:111-118.

Lovisolo C, Perrone I, Carra A, Ferrandino A, Flexas J, Medrano H, and Schubert A. 2010. Drought-induced changes in development and function of grapevine (Vitis spp.) organs and in their hydraulic and non-hydraulic interactions at the whole-plant level: a physiological and molecular update. Functional Plant Biology 37:98-116. http://dx.doi.org/10.1071/FP09191

Meinhold T, Richters JP, Damerow L, and Blanke MM. 2010. Optical properties of reflective ground covers with potential for enhancing fruit colouration. Biosystems Engineering 107:155-160. http://dx.doi.org/10.1016/j.biosystemseng.2010.07.006

Mejias-Barrera P. 2012. Effect of crushed glass, used as a reflective mulch, on Pinot noir performance M.S. Lincoln University.

Minnesota Uo. 2017. Minnesota Hardy: Grapes. Available at https:/mnhardy.umn.edu/varieties/fruit/grapes (accessed August 20 2017).

Mundy DC, and Agnew RH. 2002. Effects of mulching with vineyard and winery waste on soil fungi and botrytis bunch rot in Marlborough vineyards. New Zealand Plant Protection 55:135-138.

Nachtergaele J, Poesen J, and van Wesemael B. 1998. Gravel mulching in vineyards of southern Switzerland. Soil and Tillage Research 46:51-59. http://dx.doi.org/10.1016/S0167$\underline{1987(98) 80107-4}$ 
474 Nonnecke GR, Wasko LM, Loynachan TE, and Domoto PA. 2011. Reducing pesticide use in

475

476

477

478

479

480

481

482

483

484

485

486

487

488

489

490

491

492

493

494

495

496

497

498

499

500

501

502

503

504

505

506

507

508

509

510

511

512

513

514

515

516

517
Iowa vineyards: Alternatives to herbicides for vineyard weed management. Leopold Center Completed Grant Reports 394.

Olmstead MA. 2006. Cover crops as a floor management strategy for Pacific Northwest vineyards. Pullman, Washington: Washington State University Extension.

Olmstead MA, Wample RL, Greene SL, and Tarara JM. 2001. Evaluation of potential cover crops for inland Pacific Northwest vineyards. American Journal of Enology and Viticulture 52:292-303.

Rosenberger D, Sazo MM, Kahlke C, Mathers H, and Watkins C. 2010. Potential non-target effects of glyphosate on apples. Scaffolds Fruit Journal 19:4-9.

Ross OC. 2010. Reflective mulch effects on the grapevine environment, Pinot noir vine performance, and juice and wine characteristics M.S. Lincoln University.

Sandler HA, Brock PE, and Vanden Heuvel JE. 2009. Effects of three reflective mulches on yield and fruit composition of coastal New England winegrapes. American Journal of Enology and Viticulture 60:332-338.

Schreiner RP, and Sweet RM. 2005. Creative cover-cropping strategies for Willamette Valley vineyards. In: Papers and Posters Presented at the ASEV 56th Annual Meeting 22-24 June 2005, Seattle, Washington. American Journal of Enology and Viticulture 56:300A.

Shaulis NJ, Amberg H, and Crowe D. 1966. Response of Concord grapes to light, exposure and Geneva double curtain training. Proceedings of the American Society for Horticultural Science 89:268-280.

Smart DR, Schwass E, Lakso A, and Morano L. 2006. Grapevine rooting patterns: A comprehensive analysis and a review. American Journal of Enology and Viticulture 57:89-104.

Smart RE. 1985. Principles of grapevine canopy microclimate manipulation with implications for yield and quality. A review. American Journal of Enology and Viticulture 36:230239.

Smart RE, and Robinson M. 1991. Sunlight into wine: a handbook for winegrape canopy management. Adelaide, Australia: Winetitles.

Smart RE, Smith SM, and Winchester RV. 1988. Light quality and quantity effects on fruit ripening for Cabernet Sauvignon. American Journal of Enology and Viticulture 39:250258.

Soar CJ, and Loveys BR. 2007. The effect of changing patterns in soil-moisture availability on grapevine root distribution, and viticultural implications for converting full-cover irrigation into a point-source irrigation system. Australian Journal of Grape and Wine Research 13:2-13. 10.1111/j.1755-0238.2007.tb00066.x

Steenwerth K, and Belina KM. 2008. Cover crops enhance soil organic matter, carbon dynamics and microbiological function in a vineyard ecosystem. Applied Soil Ecology 40:359-369.

Sweet RM, and Schreiner RP. 2010. Alleyway cover crops have little influence on Pinot noir grapevines (Vitis vinifera L.) in two western Oregon vineyards. American Journal of Enology and Viticulture 61:240-252.

Tesic D, Keller M, and Hutton RJ. 2007. Influence of vineyard floor management practices on grapevine vegetative growth, yield, and fruit composition. American Journal of Enology and Viticulture 58:1-11. 
518 van Huyssteen L, Zyl JLv, and Koen AP. 1984. The effect of cover crop management on soil 519 conditions and weed control in a Colombar vineyard in Oudsthoorn. South African 520 Journal for Enology and Viticulture 5:7-17.

521 Wasko LM. 2010. Alternative weed management practices: Effects on weed control, grapevine 522 performance, and soil quality in an established midwestern vineyard M.S. Iowa State University.

Wheeler JM, Taylor BH, and Young BG. 2008. Grapevine response to groundcover management in a humid climate. In: Abstracts from Presentations at the ASEV Eastern Section 32nd Annual Meeting 15-17 July 2007, Lehigh Valley, Pennsylvania. American Journal of Enology and Viticulture 59:111A.

Wikum D, and Shanholtzer GF. 1978. Application of the Braun-Blanquet cover-abundance scale for vegetation analysis in land development studies. Environmental Management 2:323329. 10.1007/BF01866672

Williams LE. 2001. Irrigation of winegrapes in California. Practical Winery \& Vineyard Journal 23:42-55.

Williams LE, and Matthews MA. 1990. Grapevine. In: Stewart BA, and Nielson DR, eds. Irrigation of Agricultural Crops. Madison, WI: American Society of Agronomy, 10191048. 


\section{Table $\mathbf{1}$ (on next page)}

Mean daily maximum and minimum temperatures and total monthly precipitation during 2012 and 2013 growing seasons for David City, NE, 13 km from research site.

Each data point indicates the mean daily maximum and minimum temperatures and total monthly precipitation during vineyard floor management research. 
Mean daily maximum and minimum temperatures and total monthly precipitation during 2012 and 2013 growing seasons for David City, NE, $13 \mathrm{~km}$ from research site.

$\begin{array}{lcccccc} & \begin{array}{c}\text { Mean min } \\ \text { air temp, } \\ \mathbf{2 0 1 2}\left({ }^{\circ} \mathbf{C}\right)\end{array} & \begin{array}{c}\text { Mean min } \\ \text { air temp, } \\ \mathbf{2 0 1 3}\left({ }^{\circ} \mathbf{C}\right)\end{array} & \begin{array}{c}\text { Mean max } \\ \text { air temp, }\end{array} & \begin{array}{c}\text { Me12 }\left({ }^{\circ} \mathbf{C}\right) \\ \text { air temp, }\end{array} & \begin{array}{c}\mathbf{2 0 1 3}\left({ }^{\circ} \mathbf{C}\right) \\ \text { Total } \\ \text { precip, }\end{array} & \begin{array}{c}\text { Total } \\ \text { precip, }\end{array} \\ \text { March } & 3.7 & -6.5 & 18.6 & 5.6 & 15 & \mathbf{2 0 1 3}(\mathbf{m m}) \\ \text { April } & 5.8 & -0.5 & 19.8 & 12.8 & 71 & 89 \\ \text { May } & 11.2 & 8.9 & 25.9 & 21.4 & 122 & 196 \\ \text { June } & 15.7 & 14.8 & 28.8 & 27.1 & 114 & 103 \\ \text { July } & 20.3 & 17.2 & 34.5 & 29.3 & 3 & 24 \\ \text { Aug. } & 15.2 & 17.8 & 30.6 & 28.9 & 44 & 44 \\ \text { Sep. } & 9.8 & 14.0 & 27.4 & 27.1 & 6 & 71 \\ \text { Oct. } & 2.0 & 3.9 & 16.2 & 17.0 & 37 & 125\end{array}$


Table 2 (on next page)

Effects of intra-row vineyard floor management treatments on soil temperatures in a 'Marquette' vineyard

Each data point indicates the soil temperature measured under intra-row vineyard floor management treatments. 
Effects of intra-row vineyard floor management treatments on soil temperatures in a 'Marquette' vineyard planted in 2007 on a Hastings silty clay loam in Butler County, NE. CG = crushed glass mulch; $\mathrm{CRF}=$ creeping red fescue; $\mathrm{DG}=$ distillers' grain mulch; GLY = glyphosate; NSC $=$ non-sprayed control

\begin{tabular}{ccccc}
$\begin{array}{c}\text { Intra-row } \\
\text { treatment }\end{array}$ & Date & Growth stage & $\begin{array}{c}\text { Intra-row soil } \\
\text { temperature }\left({ }^{\circ} \mathbf{C}\right)\end{array}$ & $\begin{array}{c}\text { Standard } \\
\text { error }\end{array}$ \\
\hline CG & 28 May 2012 & 29 & $21.5 \mathrm{a}$ & 0.13 \\
CRF & 28 May 2012 & 29 & $19.4 \mathrm{c}$ & 0.13 \\
DG & 28 May 2012 & 29 & $21.7 \mathrm{a}$ & 0.13 \\
GLY & 28 May 2012 & 29 & $20.1 \mathrm{~b}$ & 0.13 \\
NSC & 28 May 2012 & 29 & $19.5 \mathrm{c}$ & 0.13 \\
\hline CG & 05 April 2013 & 1 & $9.0 \mathrm{a}$ & 0.10 \\
CRF & 05 April 2013 & 1 & $7.0 \mathrm{c}$ & 0.10 \\
DG & 05 April 2013 & 1 & $7.6 \mathrm{~b}$ & 0.10 \\
GLY & 05 April 2013 & 1 & $7.5 \mathrm{~b}$ & 0.10 \\
NSC & 05 April 2013 & 1 & $7.4 \mathrm{~b}$ & 0.10 \\
\hline CG & 24 May 2013 & 15 & $17.8 \mathrm{a}$ & 0.10 \\
CRF & 24 May 2013 & 15 & $15.8 \mathrm{~d}$ & 0.10 \\
DG & 24 May 2013 & 15 & $16.5 \mathrm{~b}$ & 0.10 \\
GLY & 24 May 2013 & 15 & $16.2 \mathrm{c}$ & 0.10 \\
NSC & 24 May 2013 & 15 & $15.7 \mathrm{~d}$ & 0.10
\end{tabular}

1 Notes: Growth stages were estimated using the Eichhorn-Lorenz phenological scale, as described 2 by Coombe (1995). Measurements were taken to a depth of $25.4 \mathrm{~cm}$. Within each date, means 3 followed by the same letter are not significantly different at $p<0.05$. 


\section{Table 3 (on next page)}

Vineyard inter-row soil volumetric water content

Each data point indicates the soil volumetric water content of inter-row groundcover treatments, expressed as a proportion of the VWC measured under resident vegetation. 
Vineyard inter-row soil volumetric water content $\left(\mathrm{VWC}_{\text {ratio }}\right)$, expressed as a proportion of the VWC measured in grower standard treatment (resident vegetation; RV). Vineyard floor management treatments applied to 'Marquette' grapevines planted in 2007 on a Hastings silty clay loam in Butler County, NE. KB = Kentucky bluegrass; CRF = creeping red fescue.

\begin{tabular}{ccccccc}
$\begin{array}{c}\text { Inter-row } \\
\text { treatment }\end{array}$ & $\begin{array}{c}\text { Sampling } \\
\text { date }\end{array}$ & $\begin{array}{c}\text { Growth } \\
\text { stage }\end{array}$ & VWC $_{\text {ratio }}$ & $\begin{array}{c}\text { Sampling } \\
\text { date }\end{array}$ & $\begin{array}{c}\text { Growth } \\
\text { stage }\end{array}$ & VWC $_{\text {ratio }}$ \\
\hline $\mathrm{KB}$ & $5 / 11 / 2012$ & 23 & $0.82 \mathrm{c}$ & $6 / 10 / 2013$ & 23 & $0.96 \mathrm{~b}$ \\
$\mathrm{RV}$ & $5 / 11 / 2012$ & 23 & $1.00 \mathrm{a}$ & $6 / 10 / 2013$ & 23 & $1.00 \mathrm{a}$ \\
$\mathrm{CRF}$ & $5 / 11 / 2012$ & 23 & $0.92 \mathrm{~b}$ & $6 / 10 / 2013$ & 23 & $0.99 \mathrm{ab}$ \\
\hline $\mathrm{KB}$ & $5 / 29 / 2012$ & 29 & $0.97 \mathrm{a}$ & $6 / 28 / 2013$ & 29 & $0.96 \mathrm{a}$ \\
$\mathrm{RV}$ & $5 / 29 / 2012$ & 29 & $1.00 \mathrm{a}$ & $6 / 28 / 2013$ & 29 & $1.00 \mathrm{a}$ \\
$\mathrm{CRF}$ & $5 / 29 / 2012$ & 29 & $0.98 \mathrm{a}$ & $6 / 28 / 2013$ & 29 & $0.98 \mathrm{a}$ \\
\hline $\mathrm{KB}$ & $6 / 12 / 2012$ & 32 & $0.88 \mathrm{~b}$ & $7 / 3 / 2013$ & 31 & $0.88 \mathrm{~b}$ \\
$\mathrm{RV}$ & $6 / 12 / 2012$ & 32 & $1.00 \mathrm{a}$ & $7 / 3 / 2013$ & 31 & $1.00 \mathrm{a}$ \\
$\mathrm{CRF}$ & $6 / 12 / 2012$ & 32 & $0.93 \mathrm{ab}$ & $7 / 3 / 2013$ & 31 & $0.93 \mathrm{~b}$ \\
\hline $\mathrm{KB}$ & $6 / 25 / 2012$ & 34 & $0.98 \mathrm{a}$ & $7 / 12 / 2013$ & 32 & $0.89 \mathrm{~b}$ \\
$\mathrm{RV}$ & $6 / 25 / 2012$ & 34 & $1.00 \mathrm{a}$ & $7 / 12 / 2013$ & 32 & $1.00 \mathrm{a}$ \\
$\mathrm{CRF}$ & $6 / 25 / 2012$ & 34 & $0.98 \mathrm{a}$ & $7 / 12 / 2013$ & 32 & $0.99 \mathrm{a}$ \\
\hline $\mathrm{KB}$ & $7 / 10 / 2012$ & 36 & $0.88 \mathrm{~b}$ & $7 / 26 / 2013$ & 34 & $0.86 \mathrm{~b}$ \\
$\mathrm{RV}$ & $7 / 10 / 2012$ & 36 & $1.00 \mathrm{a}$ & $7 / 26 / 2013$ & 34 & $1.00 \mathrm{a}$ \\
$\mathrm{CRF}$ & $7 / 10 / 2012$ & 36 & $0.99 \mathrm{a}$ & $7 / 26 / 2013$ & 34 & $0.98 \mathrm{a}$ \\
\hline $\mathrm{KB}$ & & & & $8 / 8 / 2013$ & 36 & $0.93 \mathrm{~b}$ \\
$\mathrm{RV}$ & & & & $8 / 8 / 2013$ & 36 & $1.00 \mathrm{a}$ \\
$\mathrm{CRF}$ & & & & $8 / 8 / 2013$ & 36 & $1.00 \mathrm{a}$
\end{tabular}

Notes: Growth stages were estimated using the Eichhorn-Lorenz phenological scale, as described by Coombe (1995). Volumetric water content was measured using time domain reflectometry. Within each date, ratios followed by the same letter are not significantly different at $p=0.05$. 


\section{Table 4(on next page)}

Vineyard intra-row soil volumetric water content

Each data point indicates soil volumetric water content under intra-row ground cover treatments, expressed as a proportion of the VWC measured under glyphosate. 
Vineyard intra-row soil volumetric water content $\left(\mathrm{VWC}_{\text {ratio }}\right)$, expressed as a proportion of the VWC measured in grower standard treatment (glyphosate; GLY). Vineyard floor management treatments applied to 'Marquette' grapevines planted in 2007 on a Hastings silty clay loam in Butler County, $\mathrm{NE}$. $\mathrm{CG}=$ crushed glass mulch; $\mathrm{CRF}=$ creeping red fescue; $\mathrm{DG}=$ distillers' grain mulch; $\mathrm{NSC}=$ non-sprayed control.

\begin{tabular}{|c|c|c|c|c|c|c|}
\hline $\begin{array}{c}\text { Intra- } \\
\text { row } \\
\text { treatment }\end{array}$ & $\begin{array}{l}\text { Sampling } \\
\text { date }\end{array}$ & $\begin{array}{c}\text { Growth } \\
\text { stage }\end{array}$ & $\mathbf{V W C}$ ratio & $\begin{array}{l}\text { Sampling } \\
\text { date }\end{array}$ & $\begin{array}{c}\text { Growth } \\
\text { stage }\end{array}$ & $\mathbf{V W C}_{\text {ratio }}$ \\
\hline $\mathrm{CG}$ & $5 / 11 / 2012$ & 23 & $0.97 \mathrm{a}$ & $6 / 10 / 2013$ & 23 & $0.94 \mathrm{~b}$ \\
\hline $\mathrm{CRF}$ & $5 / 11 / 2012$ & 23 & $0.67 \mathrm{c}$ & $6 / 10 / 2013$ & 23 & $0.93 \mathrm{~b}$ \\
\hline DG & $5 / 11 / 2012$ & 23 & $1.07 \mathrm{a}$ & $6 / 10 / 2013$ & 23 & $1.63 \mathrm{a}$ \\
\hline GLY & $5 / 11 / 2012$ & 23 & $1.00 \mathrm{a}$ & $6 / 10 / 2013$ & 23 & $1.00 \mathrm{~b}$ \\
\hline $\mathrm{NSC}$ & $5 / 11 / 2012$ & 23 & $0.81 \mathrm{~b}$ & $6 / 10 / 2013$ & 23 & $0.99 \mathrm{~b}$ \\
\hline $\mathrm{CG}$ & $5 / 29 / 2012$ & 29 & $1.02 \mathrm{~b}$ & $6 / 28 / 2013$ & 29 & $0.86 \mathrm{c}$ \\
\hline $\mathrm{CRF}$ & $5 / 29 / 2012$ & 29 & $0.86 \mathrm{~d}$ & $6 / 28 / 2013$ & 29 & $0.64 \mathrm{~d}$ \\
\hline DG & $5 / 29 / 2012$ & 29 & $1.28 \mathrm{a}$ & $6 / 28 / 2013$ & 29 & $1.56 \mathrm{a}$ \\
\hline GLY & $5 / 29 / 2012$ & 29 & $1.00 \mathrm{bc}$ & $6 / 28 / 2013$ & 29 & $1.00 \mathrm{~b}$ \\
\hline NSC & $5 / 29 / 2012$ & 29 & $0.93 \mathrm{~cd}$ & $6 / 28 / 2013$ & 29 & $0.75 \mathrm{~cd}$ \\
\hline $\mathrm{CG}$ & $6 / 12 / 2012$ & 32 & $0.95 \mathrm{a}$ & $7 / 3 / 2013$ & 31 & $0.79 \mathrm{c}$ \\
\hline $\mathrm{CRF}$ & $6 / 12 / 2012$ & 32 & $0.56 \mathrm{~b}$ & $7 / 3 / 2013$ & 31 & $0.65 \mathrm{~d}$ \\
\hline DG & $6 / 12 / 2012$ & 32 & $1.09 \mathrm{a}$ & $7 / 3 / 2013$ & 31 & $1.55 \mathrm{a}$ \\
\hline GLY & $6 / 12 / 2012$ & 32 & $1.00 \mathrm{a}$ & $7 / 3 / 2013$ & 31 & $1.00 \mathrm{~b}$ \\
\hline $\mathrm{NSC}$ & $6 / 12 / 2012$ & 32 & $0.60 \mathrm{~b}$ & $7 / 3 / 2013$ & 31 & $0.71 \mathrm{~cd}$ \\
\hline $\mathrm{CG}$ & $6 / 25 / 2012$ & 34 & $0.91 \mathrm{~b}$ & $7 / 12 / 2013$ & 32 & $0.74 \mathrm{c}$ \\
\hline $\mathrm{CRF}$ & $6 / 25 / 2012$ & 34 & $0.79 \mathrm{c}$ & $7 / 12 / 2013$ & 32 & $0.59 \mathrm{~d}$ \\
\hline DG & $6 / 25 / 2012$ & 34 & $1.23 \mathrm{a}$ & $7 / 12 / 2013$ & 32 & $1.41 \mathrm{a}$ \\
\hline GLY & $6 / 25 / 2012$ & 34 & $1.00 \mathrm{~b}$ & $7 / 12 / 2013$ & 32 & $1.00 \mathrm{~b}$ \\
\hline $\mathrm{NSC}$ & $6 / 25 / 2012$ & 34 & $0.89 \mathrm{~b}$ & $7 / 12 / 2013$ & 32 & $0.60 \mathrm{~d}$ \\
\hline $\mathrm{CG}$ & $7 / 10 / 2012$ & 36 & $1.08 \mathrm{ab}$ & $7 / 26 / 2013$ & 34 & $0.72 \mathrm{c}$ \\
\hline $\mathrm{CRF}$ & $7 / 10 / 2012$ & 36 & $0.76 \mathrm{~d}$ & $7 / 26 / 2013$ & 34 & $0.63 \mathrm{c}$ \\
\hline DG & $7 / 10 / 2012$ & 36 & $1.17 \mathrm{a}$ & $7 / 26 / 2013$ & 34 & $1.14 \mathrm{a}$ \\
\hline GLY & 7/10/2012 & 36 & $1.00 \mathrm{bc}$ & $7 / 26 / 2013$ & 34 & $1.00 \mathrm{~b}$ \\
\hline $\mathrm{NSC}$ & $7 / 10 / 2012$ & 36 & $0.87 \mathrm{~cd}$ & $7 / 26 / 2013$ & 34 & $0.68 \mathrm{c}$ \\
\hline $\mathrm{CG}$ & & & & $8 / 8 / 2013$ & 36 & $0.68 \mathrm{~d}$ \\
\hline $\mathrm{CRF}$ & & & & $8 / 8 / 2013$ & 36 & $0.64 \mathrm{~d}$ \\
\hline DG & & & & $8 / 8 / 2013$ & 36 & $1.18 \mathrm{a}$ \\
\hline GLY & & & & $8 / 8 / 2013$ & 36 & $1.00 \mathrm{~b}$ \\
\hline NSC & & & & $8 / 8 / 2013$ & 36 & $0.80 \mathrm{c}$ \\
\hline
\end{tabular}

Notes: Growth stages were estimated using the Eichhorn-Lorenz phenological scale, as described by Coombe (1995). Volumetric water content was measured using time domain reflectometry. Within each date, ratios followed by the same letter are not significantly different at $p=0.05$. 


\section{Table 5 (on next page)}

Effects of vineyard floor management treatments on intra-row percent weed cover

Each data point indicates a Braun-Blanquet weed rating for intra-row vineyard treatments on a given date. 
Effects of vineyard floor management treatments on intra-row percent weed cover in a 'Marquette' vineyard planted in 2007 on a Hastings silty clay loam in Butler County, $\mathrm{NE}$. $\mathrm{CG}=$ crushed glass mulch; $\mathrm{CRF}=$ creeping red fescue; $\mathrm{DG}=$ distillers' grain;

GLY = glyphosate; NSC $=$ non-sprayed control

\begin{tabular}{cccc}
$\begin{array}{c}\text { Intra-row } \\
\text { treatment }\end{array}$ & Date & $\begin{array}{c}\text { Braun-Blanquet } \\
\text { rating }\end{array}$ & Standard error \\
\hline CG & $9 / 7 / 2011$ & $0.0 \mathrm{c}$ & 0.22 \\
CRF & $9 / 7 / 2011$ & $1.2 \mathrm{~b}$ & 0.22 \\
DG & $9 / 7 / 2011$ & $0.0 \mathrm{c}$ & 0.22 \\
GLY & $9 / 7 / 2011$ & $1.2 \mathrm{~b}$ & 0.23 \\
NSC & $9 / 7 / 2011$ & $4.4 \mathrm{a}$ & 0.22 \\
\hline CG & $6 / 25 / 2012$ & $1.4 \mathrm{de}$ & 0.40 \\
CRF & $6 / 25 / 2012$ & $1.0 \mathrm{e}$ & 0.40 \\
DG & $6 / 25 / 2012$ & $2.2 \mathrm{~cd}$ & 0.40 \\
GLY & $6 / 25 / 2012$ & $2.6 \mathrm{abc}$ & 0.42 \\
$\mathrm{NSC}$ & $6 / 25 / 2012$ & $3.8 \mathrm{a}$ & 0.40 \\
\hline CG & $5 / 24 / 2013$ & $0.7 \mathrm{~b}$ & 0.37 \\
CRF & $5 / 24 / 2013$ & $1.7 \mathrm{~b}$ & 0.37 \\
DG & $5 / 24 / 2013$ & $0.6 \mathrm{~b}$ & 0.37 \\
GLY & $5 / 24 / 2013$ & $3.4 \mathrm{a}$ & 0.39 \\
$\mathrm{NSC}$ & $5 / 24 / 2013$ & $3.0 \mathrm{a}$ & 0.37
\end{tabular}

1 Notes: Within a date, means followed by the same letter are not significantly different at $p<0.05$.

2 Braun-Blanquet method for visual \% weed cover estimation, as described by Andújar et al.

3 (2010):

\begin{tabular}{cccc}
$\begin{array}{c}\text { Braun-Blanquet } \\
\text { rating }\end{array}$ & \% weed cover & $\begin{array}{c}\text { Braun-Blanquet } \\
\text { rating }\end{array}$ & \% weed cover \\
\hline 0 & $0-1 \%$ & 3 & $26-50 \%$ \\
1 & $1-10 \%$ & 4 & $52-75 \%$ \\
2 & $11-25 \%$ & 5 & $76-100 \%$
\end{tabular}

